\title{
SURVEI MINAT SISWA DALAM MENGIKUTI EKSTRAKURIKULER SEPAK BOLA DI SMPN 1 LEMAHABANG KARAWANG
}

\author{
Abdul Gani ${ }^{1}$ Bambang Ismaya ${ }^{2}$, Akhmad Dimyati ${ }^{3}$ \\ Program Studi Pendidikan Jasmani Kesehatan Dan Rekreasi ${ }^{123}$ \\ Fakultas Keguruan Dan Ilmu Pendidikan, Universitas Singaperbangsa Karawang \\ ganiabdul1998@gmail.com ${ }^{1}$ bambang.ismaya@ fkip.unsika.ac.id akhmad.dimyati@ fkip.unsika.ac.id ${ }^{3}$
}

\begin{abstract}
ABSTRAK
Penelitian ini bertujuan untuk mengetahui minat siswa dalam mengikuti ekstrakurikuler sepak bola di SMPN 1 Lemahabang Karawang. Penelitian ini merupakan penelitian deskriptif kuantitatif, metodeyang digunakan adalah survey study. Teknik pengumpulan data berupa angket menggunakan kuesioner pernyataan dengan 5 alternatif jawaban. Populasi yang digunakan adalah seluruh siswa yang mengikuti kegiatan ekstrakurikuler di SMPN 1 Lemahabang Karawang yang berjumlah 20 siswa. Sampel yang digunakan dalam penelitian ini sebanyak 20 siswa dengan teknik pengambilan sampel yaitu sampel penuh. Data pada penelitia dianalisis dengan menggunakan statistik deskriptif dengan presentase. Hasil penelitian menunjukan minat siswa dalam mengikuti ekstrakurikuler sepak bola di SMPN 1 Lemahabang Karawang secara keseluruhan beradapada kategori "Sangat Tinggi" mencapai angka presentase sebesar (47\%).
\end{abstract}

Kata Kunci: Survei minat, Ekstrakurikuler sepak bola.

\begin{abstract}
This study aims to determine how much the level of understanding of students in the athletic run number class XI SMK Insan Sempurna Pendidikan Karawang. This research is a descriptive quantitative research, the method used is a survey study. The data collection technique was in the form of a questionnaire using multiple choice test questions. The population used was all students of class XI SMK Insan Sempurna Pendidikan Karawang, totaling 92 students. The sample used in this study were 92 students with the sampling technique, namely saturated samples. The data in the research were analyzed using descriptive statistics with percentages. The results showed the level of understanding of students in athletics running number class XI SMK Insan Sempurna Pendidikan Karawang as a whole was in the "Enough" category with a total of 33 students and a percentage of (36\%).
\end{abstract}

Keywords: Comprehension Level, Athletics Number Running.

Dipublikasikan Oleh :

UPT Publikasi dan Pengelolaan Jurnal

Universitas Islam Kalimantan Muhammad Arsyad Al-Banjari Banjarmasin 


\section{PENDAHULUAN}

Pendidikan adalah upaya yang sangat menentukan dalam rangka meningkatkan kualitas sumber daya manusia (Saleh \& Malinta, 2020), diperkuat oleh penelitian (Ismaya, 2015) Pendidikan karakter merupakan pengembangan kemampuan pada pembelajar untuk berperilaku baik yang ditandai dengan perbaikan berbagai kemampuan yang akan menjadikan manusia sebagai makhluk yang berketuhanan (tunduk patuh pada konsep ketuhanan), dan mengemban amanah sebagai pemimpin di dunia, (Dimyati, 2019) menyatakan bahwa Pendidikan merupakan kebutuhan dasar setiap manusia untuk menjamin keberlangsungan hidupnya agar lebih bermanfaat. Pendidik dituntut untuk profesional dalam menjalankan perannya sebagai pengajar, keterampilan merancang pembelajaran adalah salah satu kemampuan pembentuk kompetensi pedagogis seorang pendidik. Sehingga dapat disimpulkan bahwa pendidikan bertujuan untuk miningkatkan sumberdaya manusia ataupun mencerdaskan anak bangsa seperti kepribadian, berbudipekerti luhur, cerdas, kreatif, disiplin, beretos kerja secara profesional, bertanggung jawab dan produktif serta sehat jasmani dan rohani.

Pendidikan jasmani (penjas) menjadi suatu proses yang amat penting dalam keseluruhan tahap pendidikan yang ada di sekolah dasar dan sekolah menengah. Dalam proses pembelajaran penjas, guru diharapkan mengajarkan berbagai keterampilan gerak dasar, teknik, permainan dan olahraga, nilai-nilai (sportifitas, jujur, kerjasama, dan lain-lain) serta pembiasaan pola hidup sehat hal ini diperkuat oleh penelitian (Majid, 2012) yang mengemukakan bahwa Pendidikan jasmani adalah suatu proses pembelajaran melalui aktifitas jasmani yang didesain untuk meningkatkan kebugaran jasmani, mengembangkan keterampilan motorik, pengetahuan dan perilaku hidup sehat dan aktif, sikap sportif, dan kecerdasan emosi. Lalu penelitian oleh (Effendi et al., 2020) Pendidikan jasmani pada dasarnya merupakan integral dari sistem pendidikan secara keseluruhan, bertujuan untuk mengembangkan aspek kesehatan, kebugaran jasmani, keterampilan berfikir kritis, stabilita emosional, keterampilan sosial. Karena dalam pendidikan jasmani siswa akan dituntun untuk bergerak, karena bergerak merupakan salah satu aspek utama dalam pendidikan jasmani. Lalu penelitian oleh (Effendi et al., 2020), Pendidikan jasmani (physical education) dipahami sebagai proses sosialisasi melalui gerak insani, bermain dan olahraga. Pendidikan jasmani mengharuskan siswa bergerak tanpa dibatasi, oleh karena itu Pendidikan jasmani merupakan satu-satunya pelajaran yang diadakan diluar ruangankelas. pendidikan jasmanin adalah suatu aktivitas fisik dan proses pembelajaran yang tersistematis dengan mengandung tiga aspek yaitu aspek afektif (sikap), aspek kognitif (pengetahuan), dan aspek psikimotor (gerak) yang bertujuan pendidikan.

Sepakbola Indonesia memiliki induk organisasi yaitu Persatuan Sepakbola Seluruh Indonesia (PSSI) organisasi ini memiliki tujuan meningkatkan prestasi di cabang olahraga sepakbola dengan mengadakan kejuaraan dan kompetisi antar klub sepakbola. Permainan sepakbola merupakan cabang olahraga yang populer dan merakyat semua golongan dapat melakukan dan menikmati sepakbola, kemenangan ditentukan oleh selisih gol yang masuk gawang lawan. Hal ini diperkuat melalui penelitian (Journal \& Kurniawan, 2021) Sepakbola merupakan suatu cabang olahraga yang sangat populer di Indonesia. Antusias perkembangan sepakbola yang sangat pesat di Indonesia tidak hanya dikalangan atlet profesional saja, namun juga masyarakat sangat menggemari permainan ini. Sedangkan (Sudirman \& Pd, 2018) menyatakhan bahwa Sepak bola merupakan salah satu cabang olahraga permainan yang sangat dikenal dan digemari masyarakat diseluruh dunia mulai dari anak-anak, remaja, maupun orang tua. Sehingga dapat disimpulkan bahwa sepak bola adalah suatu permaian beregu antara dua tim dengan masing-masing tim terdiri dar 11 orang gawang dengan bertujuan mencetak gol ke gawang lawan, yang dipimpin oleh 4 orang wasit. Adapun posisi pemain sepak bola yaitu ada penjaga gawang, pemain belakang, pemain tengah, dan pemain depan.

Hampir semua sekolah menengah pertama di tanah air memiliki kegiatan ekstrakurikuler, tentunya kegiatan ekstrakurikuler merupakan kegiatan diluar jam pelajaran sekolah dengan tujuan untuk memperluas pengetahuan dan menyalurkan bakat dan minat siswa. Dalam penelitian (Junaidi \& Nurkholis, 2017), Kegiatan ekstrakurikuler merupakan kegiatan yang baik dan penting karena memberikan nilai tambah bagi para siswa dan dapat menjadi barometer perkembangan atau kemajuan sekolah yang sering diamati oleh orang tua siswa maupun masyarakat. Adapun menurut (Sudarmono, 2018), Ekstrakurikuler yang merupakan program sekolah tidak bisa dibiarkan sebagai program yang berada diluar sistem pembinaan dan ekstrakurikuler bisa dijadikan dasar dalam sebuah sistem pembinaan yang berjenjang. Sehingga dapat disimpulkan bahwa kegiatan ekstrakurikuler merupakan kegiatan yang diselenggarakan di luar jam pelajaran yang tercantum dalam struktur program sesuai dengan keadaan dan kebutuhan sekolah, ekstrakurikuler merupakan sebuah kegiatan yang diarahkan untuk memperluas pengetahuan siswa, mengembangkan nilai-nilai atau minat dan bakat siswa.

Menurut Kamus Besar Bahasa Indonesia minat adalah keinginan yang kuat, gairah, kecendurangan hati

Dipabdikassigat ntagegi .terhadap sesuatu. Minat merupakan sumber motivasi yang mendorong individu untuk

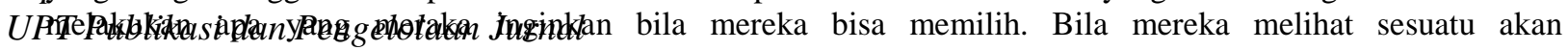


menguntungkan mereka merasa berminat. Seseorang mempunyai minat terhadap sesuatu maka perhatianya akan sendirinya tertarik pada objek tersebut. Menurut (Dimyati, 2017) Minat adalah kecenderungan yang tetap untuk memperhatikan dan mengenang beberapa kegiatan. Selanjutnya penelitian (Halim, 2013) yang menyatakan bahwa Ada pun minat atau interest merupakan gejala psikis yang berkaitan dengan objek atau aktivitas yang menstimulir perasaan senang pada individu. Adapun minat dapat dikategorikan menjadi 2 faktor, yaitu faktor intrinsik ataupun faktor yan timbul dari diri sendiri dan ekstrinsik ataupun faktor yang timbul karena adanya dorongan dari luar atau dorongan dari luar. Diperkuat oleh penelitian (Trisnawati \& Khasanah, 2013), Faktor dari dalam merupakan rangsangan yang datang dari dalam diri individu tersebut yang ruang lingkupnya sesuai dengan keinginan ataukebutuhan seseorang yang akan dengan mudah menimbulkan rasa minat terhadap sesuatu. Misal keinginan atau kecenderungan terhadap belajar, dalam hal ini seseorang mempunyai hasrat untuk ingin tahu terhadap ilmu pengetahuan. Faktor dari (intrinsik) merupakan faktor yang timbul melalui psikis individu yang meliputi rasa senang, perhatian dan emosi. Adapun (Potu, 2021), Motivasi ekstrinsik adalah motivasi yang bersumber dari luar diri yang turut menentukan perilaku seseorang dalam kehidupan seseorang yang dikenal dengan teori hygiene factor. faktor pendorong yangdatangnya dari luar individu.

Berdasarkan hasil wawancara yang dilakukan peneliti kepada siswa SMPN 1 Lemahabang Karawang mengenai minat mengikuti ekstrakurikuler sepak bola. Pada proses pelaksanaan kegiatan ekstrakurikuler sepak bola menunjukan bahwa masih ada beberapa kendala yang membuat siswa melaksanalan kegiatan tersebut, karena ketidak lengkapan sarana prasarana atau fasilitas yang digunakan untuk melakukan kegiatan ekstrakurikuler sepak bola. Lingkungan siswa pun sangat berpengaruh untuk melaksanakan kegiatan tersebut.bukan nhanya itu adapun dorongan dari pelatih, teman, dan orang tua yang sangat berpengaruh bagi siswa untuk melaksanaan kegiatan ekstrakurikuler tersebut. Hal tersebut diperkuat oleh penelitian terdahulu Novia Dwi Cahyono (2017) berjudul "Minat Siswa dalam Mengikuti Kegiatan Ekstrakurikuler Olahraga di Sekolah Menengah Atas Negeri 2 Playen Kabupaten Purbalingga”. Hasil penelitian menunjukkan diperoleh minat siswa dalam mengikuti kegiatan ekstrakurikuler olahraga di Sekolah Menengah Atas Negeri 2 Playen sebanyak 11 siswa $(12,5 \%)$ memiliki minat ekstrakurikuler olahraga dengan kategori tinggi, sebanyak 77 (87,5\%) memiliki 29 minat ekstrakurikuler olahraga dengan kategori sangat tinggi, sebanyak 0 siswa $(0 \%)$ memiliki minat ekstrakurikuler olahraga rendah, sebanyak $0(0 \%)$ memiliki minat ekstrakurikuler olahraga sangat rendah. Secara keseluruhan dapat ditarik hasilnya bahwa survey minat siswa dalam mengikuti kegiatan ekstrakurikuler olahraga di Sekolah Menengah Atas Negeri 2 Playen masuk dalam kategori sangat tinggi sebesar $87,5 \%$. Tentunya proses kegiatan eksrakurikuler menjadi bagian penting dan berpengaruh pada kemandiria dan pembentukan karakter siswa. Berdasarkan penelitian terdahulu, yang menjadi perbedaan dalam penelitian ini yaitu pertama sampel yang digunakan. Kedua, pembaharuan instrumen penelitian yang menyesuaikan minat siswa dalam mengikuti ekstrakurikuler di SMP IT-ALIKHWAN Karawang.

Dipublikasikan Oleh : 


\section{METODE}

Penelitian ini menggunakan metode deskriptif dengan pendekatan kuantitatif melalui penggunaan instrumen survey study untuk mengetahui minat siswa dalam mengikuti ekstrakurikuler sepak bola di smpm 1 lemahabang karawang.

Adapun Desain dalam penelitian yang dilakukan dalam penelitian ini menggunakan langkah langkah penelitian kuantitatif deskriptif terdiri dari : 1.) Mengidentifikasi adanya permasalahan yang signifikan untuk dipecahkan melalui metode deskriptif, 2.) Membatasi dan merumuskan permasalahan secara jelas, 3.) Menentukan tujuan dan manfaat penelitian, 4.) Melakukan studi pustaka yang berkaitan dengan permasalahan, 5.) Menentukan kerangka berpikir, dan pertanyaan penelitian dan atau hipotesis penelitian, 6.) Mendesain metode penelitian yang hendak digunakan termasuk dalam hal ini menentukan populasi, sampel, teknik sampling, menentukan instrumen, mengumpulkan data, dan menganalisis data, 7.) Mengumpulkan, mengorganisasikan, dan menganalisis data dengan menggunakan teknik statistika yang relevan, dan 8.) Membuat laporan penelitian (Literatur et al., 2020) Berikut ini merupakan kisi-kisi instrumen penelitian.

\section{Tabel 1. Kisi-Kisi Instrumen}

Survei Minat Siswa Dalam Mengikuti Ekstrakurikuler Sepak Bola Di SMPN 1 Lemahabang Karawang

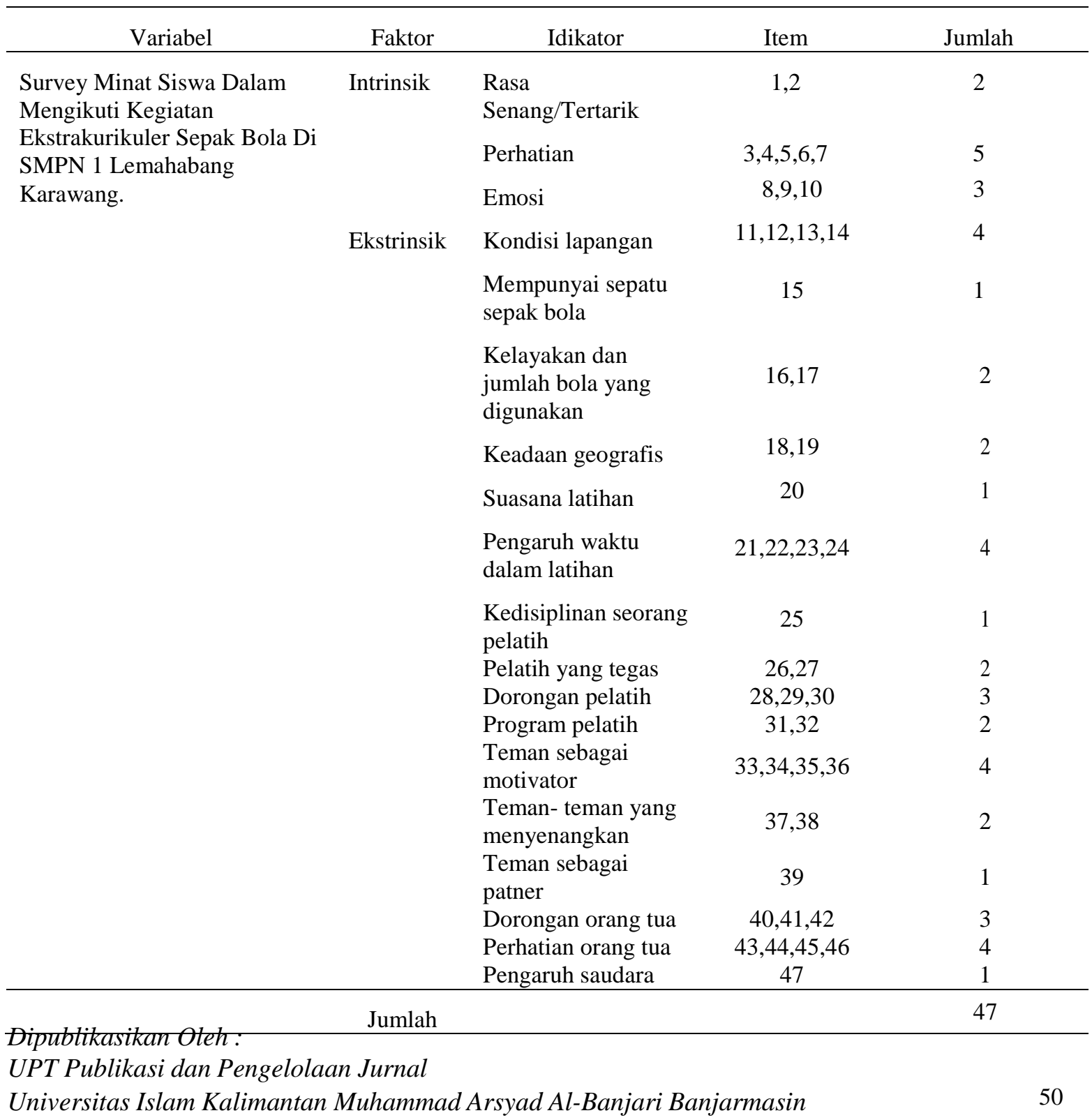


Minat siswa dalam mengikuti ekstrakurikuler sepak bola dipengaruhi oleh 2 faktor dan 19 indikator, yaitu: 1) Faktor instrinsik, yang terdiri dari 3 indikator meliputi : A) indikator rasa senang/tertrik, B) indikator emosi, dan C) Indikator perhatian. 2) Faktor ekstrinsik, yang terdiri dari 16 indikator meliputi: A) kondisi lapang, B) Mempunyai sepatu sepak bola, C) Kelayakan dan jumlah bola yang digunakan, D) Keadaan geografis, E) Suasana latihan, F) Pengaruh waktu dalam latihan, G) Kedisiplinan seorang pelatih, H) Pelatih yang tegas, I) Dorongan pelatih, J) Program pelatih, K) Teman sebagai motivator, L) Teman- teman yang menyenangkan, M) Teman sebagai patner, N) Dorongan orang tua, O) Perhatian orang tua, dan P) Pengaruh saudara. Terdapat 47 butir soal pernyataan. Teknik penilaian (scoring) yang dilakukan pada tes tersebut adalah memberikan skor 1 (satu) pada item jawaban "sangat tidak stuju", skor 2 (dua) item jawaban "tidak setuju", skor 3 (tiga) pada item jawaban (ragu-ragu), skor 4 (empat) pada item jawaban "setuju", dan skor 5 (lima) pada item jawaban "sangat setuju".

Sebelum kuisioner digunakan, maka diperlukan uji instrumen berupa uji validitas untuk mengukur ketepatan di setiap butir soal, digunakan teknik total sampling, populasi kurang dari 100 maka diambil engan keseluruhan (Mabrur et al., 2021). Butir soal dikatakan valid apabila $r_{\text {hitung }}>r_{\text {tabel }}$, untuk nilai $r_{\text {tabel }}$ dengan responden 20 orang adalah sebesar 0,444 . Setelah dilakukan perhitungan dapat diketahui terdapat 30 butir soal yang valid yaitu butir soal nomor $1,2,7,11,14,15,19,22,23,26,28,31,33,37,41,44$, dan 45 . Jadi peneliti hanya memakai 17 butir soal dari total 47 butir soal, Dan dilakukan uji reabilitas dengan menggunakan rumus alpha cronbach dengan taraf signifikansi 5\%, (Arikunto, 2013:211) suatu istrumen dikatakan reliable jika $r_{11}>r_{\text {tabel }}$, hasil uji reabilitas diperoleh nilai $\mathrm{r}_{11}=0,834>\mathrm{r}_{\text {tabel }}=0,60$ dengan demikian menunjukan angket yang diuji cobakan reliable dan dapat digunakan untuk pengumpulan data penelitian.

Tabel 2. Norma Pengkategorian

\begin{tabular}{lcc}
\hline \multicolumn{1}{c}{ Alternatif Jawaban } & Jenis Pernyataan $(+)$ & Jenis Pernyataan $(-)$ \\
\hline Sangat Setuju & 5 & 1 \\
Setuju & 4 & 2 \\
Ragu-ragu & 3 & 3 \\
Tidak Setuju & 2 & 4 \\
Sangat Tidak Setuju & 1 & 5
\end{tabular}

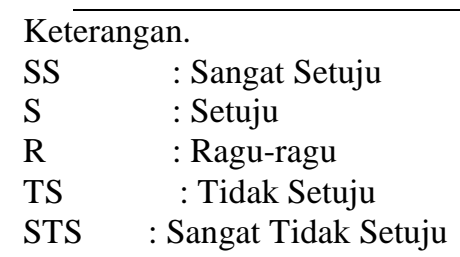

Data disajikan dalam bentuk frekuensi relatif yang yang dituangkan dalam bentuk angka prosentase. Untuk memperoleh persentase digunakan rumus:

Keterangan:

$\begin{array}{ll}\mathrm{p} & : \text { angka persentase } \\ \mathrm{n} & \text { : frekuensi } \\ \mathrm{N} & \text { : jumlah subjek/ responden }\end{array}$

Dipublikasikan Oleh : 


\section{HASIL DAN PEMBAHASAN}

Berdasarkan hasil penelitian yang telah diperoleh dilapangan mengenai Minat Siswa Dalam Mengikuti Ekstrakurikuler Sepak Bola Di SMPN 1 Lemahabang Karawang, Peneliti akan mendeskripsikan dan menganalisis data tersebut menggunakan metode deskriptif dengan pendekatan kuantitatif. Untuk memperoleh data dalam penelitian ini , peneliti menggunakan instrumen survey study menggunakan kuisioner berupa soal dengan 5 (lima) alternatif jawaban. Dari hasil penelitian yang diperoleh, minat siswa dalam mengikuti ekstrakurikuer sepak bola di smpn 1 lemahabanag di kategorikan menjadisa 5 kategori yaitu, kategori sangat tinggi, tinggi, sedang, rendah dan sangat rendah. Sehingga statistik deskriptif mengenai, minat siswa dalam mengikuti ekstrakurikuer sepak bola di smpn 1 lemahabanag dapat dilihat pada table berikut.

\section{Tabel 3. Hasil Statistik Deskriptif Penelitian}

\begin{tabular}{lccc}
\hline \multicolumn{1}{c}{ Keterangan } & $\begin{array}{c}\text { Keseluruhan } \\
\text { (Minat Siswa) }\end{array}$ & Faktor Intrinsik & Faktor Ekstrinsik \\
\hline Sangat tinggi & 47,94 & 36,6 & 50,35 \\
Tinggi & 24,11 & 6,66 & 27,85 \\
Cukup & 16,07 & 26,66 & 10,35 \\
Rendah & 4,70 & 5 & 4,64 \\
Sangat rendah & 10 & 25 & 6,78 \\
\hline \multicolumn{1}{c}{ Jumlah (\%) } & 100 & 100 & 100 \\
\hline
\end{tabular}

Hasil analisis data statistic penelitian secara keseluruhan memperoleh nilai minat kategori sangat tinggi 47,94, kategori tinggi sebesar 24,11, cukup sebesar 16,07, rendah sebesar 4,70, sangat rendah sebesar 10, dan nilai maksimal sebesar 100. Hasil analisis data penelitian faktor intrinsik mencapai angka presentase 36,6 dengan kategori sangat tinggi, kategori tinggi mencapai 6,66, kategori cukup mencaai presentase 26,66, kategori rendah mencapai angka presentase 5, dan kategori sangat rendah mencapai 25. Adapun analisis data faktor ekstrinsik mencapai angka presentase 50,35 dengan kategori sangat tinggi, kategori tinggi mencapai angka presentase 27,85, kategori cukup mencapai angka presentase mencapai 10,35, kategori rendah mencapai 4,64, dan kategori sangat rendah mencapai presentase 6,78.

Tabel 4. Distribusi Frekuensi Jawaban Responden Pada Komponen Minat

\begin{tabular}{lc}
\hline \multicolumn{1}{c}{ Keterangan } & $\begin{array}{c}\text { Keseluruhan } \\
\text { (Minat Siswa) }\end{array}$ \\
\hline Sangat tinggi & 47,94 \\
Tinggi & 24,11 \\
Cukup & 16,07 \\
Rendah & 4,70 \\
Sangat rendah & 10 \\
\hline \multicolumn{1}{c}{ Jumlah (\%) } & 100 \\
\hline
\end{tabular}

FaktorIntrinsik.

Minat untuk mengikuti ekstrakulikuler dari faktor intrinsik didasari atas rasa senang atau muncul dari dalam individu itu sendiri tanpa ada paksaan dari luar, misal dari orang tua, teman atau guru. Minat ini muncul karena adanya rasa bersaing sportif, ingin menambah pengalaman tentang sepak bola, menjaga kondisi agar tetap sehat, rasa untuk mencetak prestasi pada diri individu dan lainnya. Selain itu mereka mengikuti kegiatan eksrakulikuler sepak bola diharapkan bisa memberikan contoh kepada siswa lain yang merasa belum mampu bermain sepak bola maupun kepada masyarakat dimana ia bertempat tinggal, dan juga mereka merasa tertarik untuk mengikutinya karena adanya prestasi yang pernah diraih oleh sekolahannya. Dengan mengikuti ekstrakulikuler di sekolah mereka akan lebih berpengalaman dalam bermin sepak bola, bahkan untuk kesiapan diri mereka dalam menghadapi kompetisi sepak bola antar sekolah. 


\section{Tabel 5. Distribusi Frekuensi Jawaban Responden Pada Komponen Faktor Intrinsik}

\begin{tabular}{lc}
\hline Keterangan & Faktor intrinsik \\
\hline Sangat tinggi & 36,6 \\
Tinggi & 6,66 \\
Cukup & 26,66 \\
Rendah & 5 \\
Sangat rendah & 25 \\
\hline Jumlah (\%) & 100 \\
\hline
\end{tabular}

\section{Faktor Ekstrinsik}

Minat untuk mengikuti ekstrakulikuler dari faktor ekstrinsik didasari atas dorongan dari luar yaitu seperti dorongan sarana prasarana, lingkungan, orang tua/keluarga, teman atau guru/pelatih. Minat ini muncul karena adanya perhatian orang tua, ajakan teman, fasilitas yang memadai, sutuasi latihan nyaman. Dengan mengikuti ekstrakulikuler di sekolah mereka akan lebih berpengalaman dalam bermin sepak bola, dapat memperluasa wawasan bermain sepak bola, berprestasi dalam bidang sepak bola adapun dukungan dari orang tua yang membuat siswa semangat berlatih.

Tabel 6. Distribusi Frekuensi Jawaban Responden Pada Komponen Faktor Ekstrinsik

\begin{tabular}{ll}
\hline \multicolumn{1}{c}{ Keterangan } & Faktor Ekstrinsik \\
\hline Sangat tinggi & 50,35 \\
Tinggi & 27,85 \\
Cukup & 10,35 \\
Rendah & 4,64 \\
Sangat rendah & 6,78 \\
\hline \multicolumn{1}{c}{ Jumlah (\%) } & 100
\end{tabular}

\section{PENUTUP}

Berdasarkan hasil penelitian dan pembahasan, maka dapat disimpulkan bahwa: pertama, minat siswa dalam mengikuti ekstrakurikuler sepak bola di smpn 1 lemahabang karawang adalah sangat tinggi. Kedua,minat siswa dalam mengikuti ekstrakurikuler sepak bola dengan pengaruh faktor intrinsik dapat diketegorikan sangat tinggi. Ketiga, adapun faktor ekstrinsik siswa dalam mengikuti ekstrakurikuler sepak bola dapat dikategorikan sangat tinggi. Hasil penelitian ini diharapkan bisa meningkatkan minat siswa untuk mengikuti kegiatan ekstrakurikuler sepak bola di smpn 1 lemahabang.

\section{REPERENSI}

Dimyati, A. (2019). Tingkat Kejenuhan Guru dalam Mengajar Pendidikan. Jurnal Ilmiah Penjas, 5(2), 37-47. Dimyati, A., \& Aminah, A. S. (2017). Pengaruh Fun Outbound Untuk Meningkatkan Motivasi. 153-158.

Effendi, R., Susianti, E., \& Aminudin, R. (2020). Minat Siswa Terhadap Pembelajaran Bola Voli Kelas 8 Pada SMPN 7 Karawang Barat. Jurnal Literasi Olahraga, 1(1), 8-18.

Halim, S. (2013). MINAT SISWA SMA Dr. SOETOMO SURABAYA PADA KEGIATAN EKSTRAKURIKULER FUTSAL. Jurnal Pendidikan Olahraga Dan Kesehatan, 1(1), 260-264.

Ismaya, B. (2015). Model Kepemimpinan Sekolah Berkarakter Untuk Meningkatkan Mutu Pendididikan Bambang. Jurnal Pendidikan Unsika, 3 Nomor 1(Maret 2015), 97-108.

Kurniawan, F. (2021). KENCAN ILMIAH : APA YANG BISA DILAKUKAN AKADEMISI. 2(2), 181-185.

Junaidi, S., \& Nurkholis, M. (2017). Minat Siswa Putra Dalam Mengikuti Kegiatan Ekstrakurikuler Sepakbola Di Smp Negeri 2 Srengat Kabupaten Blitar Tahun Pelajaran 2016 / 2017 The Interest Of Boy Students In The Following Activities Extracurricular Soccer In Smp Negeri 2 Srengat Blitar. 
Literatur, S., Pendekatan, A., Taktis, P., Hasil, T., Dan, P., Dalam, D., \& Sepakbola, K. (2020). BAB I.

Mabrur, M., Setiawan, A., \& Mubarok, M. Z. (2021). Pengaruh Model Pembelajaran Direct Instruction Terhadap Hasil Belajar Teknik Dasar Guling Depan Senam Lantai. Physical Activity Journal, 2(2), 193.

Majid, M. I. (2012). Pendidikan Jasmani Di Sdlb. 1-92.

Potu, J., Lengkong, V. P. K., Trang, I., \& Lengkong, V. P. K. (2021). PENGARUH MOTIVASI INTRINSIK DAN MOTIVASI EKSTRINSIK TERHADAP KINERJA KARYAWAN PADA PT . AIR MANADO THE INFLUENCE OF INTRINSIC MOTIVATION , AND EXTRINSICT MOTIVATION ON EMPLOYEE PERFORMANCE AT PT . AIR MANADO Jurnal EMBA Vol . 9 No . 2 April 2021, Hal . 3. 9(2), 387-394.

Saleh, M. S., \& Malinta, S. S. (2020). Survei Minat Belajar Siswa Dalam Mengikuti Pembelajaran Pendidikan Jasmani Di Smpn 30 Makassar. Kinestetik, 4(1), 55-62.

Sudarmono, M., Annas, M., \& Hanani, S. (2018). Sistem Pembinaan Ekstrakurikuler Sepakbola Di Kabupaten Banyumas. Jurnal Penjakora, 5(1), 64-75.

Sudirman, P. I. I., \& Pd, M. (2018). Ekstrakurikuler Sepak Bola.

Trisnawati, Y., \& Khasanah, K. (2013). ANALISIS FAKTOR INTRINSIK DAN EKSTRINSIK YANG BERPENGARUH TERHADAP INFEKSI SALURAN PERNAPASAN AKUT ( ISPA ) PADA BALITA TAHUN 2013 Yuli Trisnawati \& Kuswatin Khasanah Akademi Kebidanan YLPP Purwokerto. Jurnal Kebidanan, $V(01), 43-53$.

Dipublikasikan Oleh : 